\title{
Artium
}

Architecture, Urbanism, Design and Construction Vol. 9, Issue 2, August 2021

Journal homepage: http://artium.hku.edu.tr

DOI: $10.51664 /$ artium. 880347

\section{Tarihi Yapıların Yeniden İşlevlendirilmesi: Kayseri Lisesi Örneği}

\author{
Zeynep BAHAR ${ }^{1}$, Funda KURAK AÇICI ${ }^{2}$ \\ 1 YL Öğr., Karadeniz Teknik Üniversitesi, Mimarlık Fakültesi, İç Mimarlık Bölümü, Trabzon / TÜRKIYE \\ ORCID ID: 0000-0002-8830-0504 \\ 2 Doç. Dr., Karadeniz Teknik Üniversitesi, Mimarlık Fakültesi, İç Mimarlık Bölümü, Trabzon / TÜRKIYE \\ ORCID ID: 0000-0003-2592-2266
}

ÖZ

Kayseri Lisesi, Kayseri’nin Geç-Osmanlı dönemi eserlerinden birisidir. Sahip olduğu neo-klasik mimari tarz ile Kayseri'nin taşınmaz kültür envanterlerinde yer almaktadır. Yapının Kayseri kent tarihi ve dokusundaki öneminden dolayı Kayseri Lisesi çalışma alanı olarak belirlenmiştir. Yapı, zamanın getirdiği ihtiyaçlar ve imkânlar doğrultusunda yeniden işlevlendirilmiş ve işlev değișimleri sonucunda da yapıda mekânsal değişiklikler meydana gelmiştir. Çalışmada yapının tarihi dokusu ve yapısal özellikleri ile geçmișten günümüze kadar yaşadığı değișimlerin ortaya koyulması hedeflenmektedir. Bu amaç doğrultusunda yapıya dair işlev değişimlerinin anlatıldığı plan ve fotoğrafların yer aldığı belgelere ulaşılmıştır. Bu belgelerin ıșı̆ı̆ında yapının geçirmiș olduğu değişim süreci ile işlev gereği yapılan mekânsal ihtiyaç ve müdahaleler oluşturulan analizler üzerinden irdelenmiştir. Çalışmada değerlendirme başlıklarına yönelik oluşturulan analiz çizelgeleri, yapının geçirmiş olduğu değişimleri aktaran bir kaynak olması yönüyle literatüre katkı sağlamaktadır. Yapının değişimi ve taşıdığı değerler incelendiğinde ise, yapının formunun ve yapısal özelliklerin neredeyse birçoğunun günümüze kadar taşındığı ama iç mekân malzeme özelliklerinin taşınmasında aynı duyarlılığın gösterilmediği, zaman içindeki mekânsal değişimlerin daha fazla olduğu sonucuna varılmıştır.
Araștırma Makalesi

Research Article
MAKALE BİLGISİ
Geliş : 15 / 02 / 2021
Kabul: 02 / 05 / 2021

ANAHTAR KELIMELER

Tarihi Yapı

Yeniden İşlevlendirme

Kayseri Lisesi

Taş Mektep

Milli Mücadele Müzesi

\section{Refunctioning of Historical Buildings: Case of Kayseri High School}

\begin{abstract}
Kayseri High School is one of the late-Ottoman period works of Kayseri and is included in the immovable cultural inventories of Kayseri with its neo-classical architectural style. Due to the importance of the building in Kayseri urban fabric and history, Kayseri High School has been determined as a study field. The building has been re-functionalized in line with the needs and possibilities of time, and spatial changes have occurred as a result of functional changes. In the study, it is aimed to reveal the historical texture and structural features of the building and the changes it has experienced from the past to the present. For this purpose, documents including plans and photographs describing the functional changes of the building were reached. In the light of these documents, the process of change that the building has undergone and the spatial needs and interventions made for the function were examined through the analysis created. Analysis charts created for the assessment titles in the study contribute to the literature as it is a source that conveys the changes that the structure has undergone. When the changes the building has undergone and the values it carries are examined, it is concluded that almost most of the form and structural features of the building have been carried until today, but the same sensitivity is not shown in the transportation of the interior material properties, and that spatial changes over time are seen more.
\end{abstract}

ARTICLE HISTORY

Received 15/02/2021

Accepted 02 / $05 / 2021$

\section{GíRIŞ}

Tarihi yapılar toplumun tarihi hakkında bilgiler sunan, kültürünü yansitan ve ait olduğu dönemin mimari üslubu hakkında izlerin okunabildiği eserlerdir. Dolayısıyla tarihi öğrenme, deneyimden yararlanma, geleceğe örnek olma ve gelecek kuşaklara belge olarak aktarma hedefi, geçmişin tanığı olan bu eserleri korumak için önemli bir sorumluluk getirmektedir (Aydın ve Yaldız, 2010). Koruma toplumun geçmişi ile geleceğini birbirine bağlama çabası olarak değerlendirilmektedir. Kültürel varlığa doğrudan bir müdahale olan koruma (Feilden 1982); tarihsel veya sanatsal değeri olan yapıların veya dokuların devam etmesi için gerekli bir önlem olarak ifade edilmektedir 
(Hasol, 1988; Akt. Yalaz ve Yaldı, 2020). Bozulmayı önleme eylemi olan koruma, aynı zamanda doğal ve kültürel çevrenin maddi ve manevi değerlerinin korunması ve geleceğe aktarılma sürecidir (Feilden, 1982).

Korumanın temel sorunlarından biri ise neyin korunacağ olmaktadır. Antik çağlardan günümüze kadar gelebilen Pantheon gibi dini eserler, Piramitler gibi mezar anıtları, ya da işlevsel binalar dünya mimari mirası öğeleri olarak koruma altına alınması gerekli yapılar olmuştur. Aynı zamanda anitsal olmayan ve tamamen işlevsel amacı olan gündelik yaşama ait yapılar da zaman geçtikçe topluma ait sosyal bir bileşen olarak değer kazanarak koruma altına alınmaktadır. Geçmişten kalan izlerin tümünün gelecek kuşaklara aktarılması mümkün olamamaktadır. Ülkelerin ekonomik kaynakları, böyle bir çabayı destekleyememektedir. Bakımsızlık, malzemenin yıpranması, doğal afetler, çağdaş kentleşme sorunları ile tarihi yapıların sayısı azalma göstermektedir. Bu nedenle, öncelikle korunması gerekli, vazgeçilmez, ya da korunması rastlantılara birakılamayacak eserlerin seçimine yardımcı olabilecek ölçütlerden yararlanılmaktadır (Ahunbay, 2009). Bu ölçütler, tarihi belge niteliği, eskilik(zaman) özelliği, estetik değer yönlerinden sahip olduğu öneme bağlı olarak alınmaktadır (Kuban, 1970). Korumaya değer görülen yapıların korunmasında başvurulabilecek belli koruma yöntemleri bulunmaktadır. Bunlar, sağlamlaștırma, bütünleme, yenileme (yeniden kullanım, yeni işleve uyarlama), yeniden yapma, temizleme ve taşımadır. Kültürel ve tarihi miras olarak geçmişle ve gelecekle olan bağ temsil eden tarihi yapılara yeni bir işlev verilmesi, en çok kullanılan koruma yöntemlerinden birisidir. Tarihi yapilara uygulanan işlev değişikliği koruma yaklaşımına çağdaş bir yorum olarak ifade edilmektedir (Ahunbay, 2009).

Günümüzde tarihi yapılar ihmal, yanlış malzeme ve teknik kullanımı gibi sebeplerden dolayı onarılamayarak ya da korunamayarak tahrip edilmiş ya da kullanılamaz duruma gelmiştir. Tarihi yapıların işlevlerini sürdürememelerinin nedenleri yapıların özgün işlevlerini kaybetmeleri ve işlevsel olarak eskimeleri olarak özetlenebilmektedir (Altınoluk, 1998; Aydın ve Şahin, 2018). Geçmişin tarihi ve kültürel birikiminin gelecek kuşaklara aktarılmasını sağlayan tarihi yapıların korunması kavramı son yıllarda önemi gittikçe artan konuların başında gelmektedir. Çağdaş koruma yaklaşımında; dondurularak koruma anlayışından uzaklaşılarak, kültür varlığının çağın gerekleri doğrultusunda yaşatılarak korunmasına yönelik uygulamalar ön plana çıkmaktadır (Pereira, 2007). Koruma yöntemlerinden biri olarak öne çıkan yaşatılarak koruma, yeniden işlevlendirmenin de temelini oluşturmaktadır.

Yeniden işlevlendirme, tarihi değer taşıyan yapıların ve alanların sonraki nesillere ulaşabilmesi, kültürel sürekliliğin sağlanması, yap1 ve alanların yeniden değerlendirilerek ekonomik ve kültürel ortama katkısının artırılabilmesi, mevcut çevrenin güzelleştirilerek kentin ihtiyaçlarını karşılaması için gerekli bir uygulama olarak nitelendirilebilir (Gazi ve Boduroğlu, 2015). Özgün nitelikleriyle geleceğe aktarılan tarihi bir unsurun toplumsal değişim içinde yok olması engellenmiş olur. Böylece gelecek kuşaklara iletilen tarihi miras ile kültürel süreklilik sağlanmış olur (Yalçınkaya vd, 2019). Yapılan restorasyon çalışmaları ile yapıların yeniden kullanımında seçilecek yeni işlevlerle yapıların korunması ve gelecek kuşaklara aktarılması mümkün olabilmektedir (Aras, 2020).

Bu çalışmanın konusu olarak, Kayseri kenti için, taşıdığı tarihi miras değeri yönünden Kayseri Lisesi'nin ele alınması uygun görülmüştür. Yapının, şair Ahmet Remzi Dede'nin yapı ile ilgili yazmış olduğu şiir üzerinden yapılan ebced hesabı ile 1904 yılında inşa edildiği kabul edilmektedir (Kültür ve Turizm Müdürlüğü, 2009). Yap1, II. Abdülhamid zamanında yapılmış ve Geç-Osmanlı dönemi eserlerindendir. Yap1, Türkiye'nin en eski fakat hala ayakta duran eğitim kurumu (Arslantaş, 2009) olması ve belgesel, tarihsel ve estetik / mimari değere (Gül Asatekin, 2004) sahip olması korunmasının gerekliliğini göstermektedir. $\mathrm{Bu}$ çalışma kapsamında Kayseri Lisesi'nin yeniden işlevlendirme sonucunda, tarihi dokusu üzerinde bir değişim olup olmadığı üzerinden değerlendirilmesi hedeflenmektedir. Yapının tarihi dokusunda hem yıllar içinde hem de işlev değişikliği ile meydana gelen değişimleri ortaya koymak amaçlanmaktadır. Çalışmanın bir sonraki bölümünde tarihi yapıların yeniden işlevlendirilmesi, yeniden işlevlendirme gerekçeleri ve tarihi yapılara müze işlevi verilmesi hakkında literatüre dayalı bilgi verilmekte, ikinci bölümünde bulgular başlığında çalışma alanına, yapının tarihçesi ve mimari özelliklerine ve yapının işlevsel değişim ve zamana bağlı değişimler analizine yer verilmektedir. Son bölümde de sonuçlar tartışılmaktadır.

\section{Tarihi Yapıların Yeniden İşlevlendirilmesi}

Tarihi yapılar kentlere kimlik kazandıran ve kentin geçmişine tarihsel ve kültürel bir okuma sağlayan önemli eserler olarak değerlendirilmektedir. Küreselleşme ve yapılaşmanın etkisi ile tarihi yapılar modern yapıların arasında kaybolmakta ve bunun sonucu olarak da zaman içinde kentler, kimliğini kaybetmeye başlamaktadır. Tarihi yapıların mevcut durumları üzerinden topluma yeniden kazandırılabilmesi ve kültürel - tarihsel sürdürülebilirliğin sağlanabilmesi için yapılara bakım ve onarım yapılması gerekmektedir. Yapılardaki bakım ve onarım çalışmaları olarak karşımıza restorasyon kavramı çıkmaktadır.

Restorasyon, bir sanat eserinin ya da tarihi şahitlik yapmış herhangi bir şeyi korumak ve gerektiğinde mümkün olduğu kadarı ile ilk haline getirmek amacı ile yapıtı ya da şeyi sağlamlaştırmaya ve yıpranma sürecini durdurmaya yönelik yapılan çalışmaların hepsidir şeklinde tanımlanabilmektedir (Hasol, 2005).

Restorasyonun amacı, tarihi yapılara mümkün olduğunca az müdahale edilerek tarihi değerinin korunmasını sağlamaktır. Restorasyonun birkaç türü bulunmaktadır. Bunlar; Sağlamlaştırma, Bütünleme (Reintegrasyon), Yenileme, Yeniden İşlevlendirme (RenovasyonRehabilitasyon), Yeniden Yapım (Rekonstrüksiyon), Temizleme, Taşımadır (Kocabıyık, 2014; Kurak Açıcı ve Konakoğlu, 2019). Tarihi yapıları koruma türlerinden olan yeniden işlevlendirme, içinde bulunulan toplumun zamanla farklılaşan ihtiyaçlarına bağlı olarak, özgün işlevini kaybeden mimari mirasın yeniden kullanılması olarak adlandırılmaktadır (Eraybat, 2011; Plevoets ve Van 
Cleempoel, 2011). Yeniden kullanımın amac1, kültür varlığının taşımış olduğu tarihi, estetik ve özgünlük gibi değerlerinin yaşatılmasıdır (Ahunbay, 2013). Bu durumda korumanın en büyük amacı ise yapının taşımış olduğu değerler ve çevresi ile bütün olarak düşünerek yeni işlev ile kullanılıp yaşatılmasıdır (Yaldız ve Asatekin, 2016).

Yeniden işlevlendirme eski yapıların harap olması ve yıkımdan kurtarılması için kullanılabilecek bir araç olmaktadır (Ahunbay, 2009). Kültürel miras niteliğindeki bu yapıların yeniden işlevlendirilmesi yönünde ulusal ve uluslararası ölçekte tüzük, yönetmelik ve karalar bulunmaktadır. Türkiye'de koruma kapsamını etkileyen düzenlemeler Kültür ve Tabiat Varlıklarını Koruma Kanunu ile koruma kurullarının yönetmelikleridir. Tarihi ve kültürel taşınmaz varlıkların yenilenerek korunması ve yaşatılarak kullanılması amacıyla 05.07.2005 tarih ve 25866 sayılı Resmî Gazete'de "Yıpranan Tarihi ve Kültürel Taşınmaz Varlıkların Yenilenerek Korunması ve Yaşatılarak Kullanılması Hakkında Kanun" yayımlanmıştır (Aydın ve Şahin, 2018). Yeniden işlevlendirme konusunda yapılan ilk gelişmelerden biri olan Madrid Konferans1 Tavsiye Kararları: Altınc1 uluslararas1 Mimarlar Kongresi (RIBA 1904)'dir. Bu kongrede alınan kararların 3.maddesinde, "Mimarlıta ise yararlı, güzelliğin esaslarından biri olduğu için, yasayan eserler yeniden kullanılmaları için onarılmalıdır" ifadesi yer almıștır (Yalaz ve Yaldız, 2020). Carta del Restauro, ICOMOS 1931 tüzüğünün 4. maddesinde "Yaşayan, yani ayakta duran anıtlara, yalnızca özgün işlevinden çok uzak olmayan ve binada gerekli uyarlamaların önemli hasara neden olmayacak şekilde yapılabileceği yeni kullanımlar verilmesi kabul edilebilir." ifadesi yer almaktadır (Ahunbay, 2009). Venedik Tüzüğü'nün yeniden işlevlendirme ile ilgili onarım ilkeleri konusundaki 5. maddesinde ise, "Anıtların korunmast, her zaman onlart herhangi bir yararlı toplumsal amaç için kullanmakla kolaylaştırllabilir. Bunun için bu tür kullanma arzu edilebilir, fakat bu nedenle yapının planı, ya da bezemeleri değiştirilmemelidir. Ancak bu sinırlar içinde yeni işlevin gerektirdiği değişiklik tasarlanabilir ve buna izin verilebilir (Venedik Tüzüğü, 1964) ifadesi ile tarihi yapılarının önemli tarihsel, estetik öğelerinin korunması sağlanarak yapıların yeniden kullanılabileceği belirtilmiştir. Koruma sağlanabilmesi için yapıların devamlı olarak kullanılması gerekmektedir. Bunun için de yapılara toplumsal bir işlev vermenin yapı ve anıtların yaşamlarını devam ettirmeleri için gerekli olduğu görülmektedir (Erder, 1977).

Anıtsal bir yapıyı yeni işlev ile tekrardan kullanıma sunmak insan-yapı arasında bütünleşme sağlamaktadır. Bu bağlamda da yeniden işlevlendirmenin amacı kültürel miras değeri taşıyan yapının tüm tarihsel, estetik ve özgünlük değerlerinin korunarak müdahalelerde bulunmasıdır (Ahunbay, 2009). Zamana karşı hala ayakta kalmayı başarabilen ve günümüze gelen anıtsal yapılar, yen işlev ile beraber yeniden örgütlenmesi, geçmiş ve gelecek arasındaki bağlantıyı sürdürdüğü ve yok olmasının önüne geçilmesi kadar ekonomik olma, sürekli kullanım, çevresel enerji tüketiminin azalması, kent siluetine katkı sağlaması gibi avantajlar sağlamaktadır (Altınoluk, 1991; Özdemir vd., 2005; Langston et al., 2008; Aydın ve Yaldız, 2010). Aynı zamanda yeni işlevle beraber yapılar yaşayan varlık konumuna gelerek sosyal yaşama katılmaları sağlanmaktadır (Altınoluk, 1998; Yaldız ve Asatekin, 2016).

Yeniden işlevlendirilen tarihi yapıda, tasarımı belirleyen en önemli etmen, yapının tarihini yansıtan tüm verilerinin korunması olmaktadır (Kuban, 2000). Tarihsel ve kültürel sürdürülebilirliğin sağlanması yönünde yapılan yeniden ișlevlendirme de yapının mimari özelliklerine, mekânsal kurgu ve çevresel faktörlerine önem verilerek yapılması sayesinde yapıların toplum hayatına kazandırılmasının söz konusu olabileceği belirtilmektedir. Tarihi yapılara yapılan restorasyon türleri içinden yapının yeniden işlevlendirilme türünün seçilmesinde bazı gerekçeleri olabilmektedir. Bir sonraki konu başlığında tarihi yapıların yeniden işlevlendirme gerekçelerinden bahsedilmektedir.

\section{Tarihi Yapıların Yeniden İşlevlendirme Gerekçeleri}

Tarihi yapıların zaman içinde özgün fonksiyonlarını kaybetmesi ve binaların işlev olarak eskimeleri nedeniyle yeniden işlevlendirilmesi önerilmektedir. Tarihi yapıların yeniden işlevlendirme gerekçeleri tarihi ve kültürel faktör, çevresel faktör ve ekonomik faktör olarak toplam 3 başlıkta incelenebilmektedir (Karadayı Yenice ve Altınoluk, 2019):

Bunlardan ilki olan tarihsel ve toplumsal faktör, toplumsal yapıda zamanla değişen yaşam koşulları, ihtiyaçlar ve değerler gittikçe farklılaşmaktadır (Kocabıyık, 2014). Buna bağlı olarak bu kadar büyük bir değişim içinde işlevler değişebilmekte fakat yapılar aynı kalmaktadır. Bu durum ileri zamanlarda eski ve yeni yapılar için farklı fonksiyonlara sahip yeni kullanımlar gerektirebilmektedir. Yapılan her bir yapı o zamanın, o günün ve o şehrin ihtiyaç duyduğu işleve yönelik zamanın imkan ve koşullarına göre inşa edilmektedir (Warren et al., 1998). Günümüzde o işleve gerek olmayabilir fakat tarihi, sosyal ve ekonomik nedenler yapının kullanılmasını gerektirebilmektedir (Karadayı Yenice ve Altınoluk, 2019). Aynı zamanda mevcut yapının yıkılarak yeni baştan inşa edilmesi yerine yeniden işlevlendirilip, değerlendirilmesi her yönden olumlu bir karar olarak ortaya çıkmaktadır. Tarihi yapı yok edilirse, özgün işlevinin ve tarihteki yerinin toplumsal bellekte oluşturduğu yer silinmiş olduğundan, yerine yeni bir veri girilerek toplumsal kimlik ve bellek zarar görmüş olmaktadır (Kaşlı, 2009). Tarihi yapıları toplum için önemli bir kaynak olarak değerlendirerek kullanılmasının yanı sıra yapının yaşatılması ve gelecek nesillere aktarılacak kültürel bir ürün olarak görülmesi yapılara yaklaşımda doğru bir bakış açısı oluşturabilmektedir (Cantacuzino, 1989; Kee, 2019).

İkinci faktör ise yapının çevresi ile olan etkileşimi, yapının yeniden işlevlendirilmesini gerekli kılan nedenlerden olmuştur. Çünkü anıtsal mimari yapılar çevreleri ile bir bütündür ve çevrelerinde meydana gelen her türlü olumsuzluklar yapıların yıpranmalarına neden olmaktadır (Yaldız, 2003). Aynı zamanda yapının yer aldığı bölgenin değişimi ile fonksiyon değişiminin de gerekli hale gelmesidir. Yeni işlev verilecek olan yapının çevre bakımından uyumu göz önünde bulundurularak ihtiyaç duyulan işlevin belirlenmesi sayesinden yapının toplum belleğindeki yeri korunmuş olmaktadır (Kocabıyık, 2014). Ayrıca yeniden işlevlendirme mevcut yapıyı koruyarak 
sürdürülebilirliği sağlaması ve yapının yıkılıp tekrar yapılması gibi çevreye herhangi bir zararı olmaması yönünden de düşünüldüğünde çevreye duyarlı, doğal kaynakların daha az kullanıldığı ve doğal çevrenin daha az kirletildiği bir üretim tekniği ile şekillenmektedir (Selçuk, 2006).

Son olarak, fiziksel olarak kullanılabilir durumda olup işlevsel olarak eski kalan bir yapıyı yeniden işlevlendirerek tekrardan kullanılacak hale getirmek daha az iş gücü, enerji, maliyet, malzeme harcanması ile ekonomik bir fayda sağlamakta ve zamandan da kazandırmaktadır (Kaşlı, 2009). Kısacası belli bir işlev için eski bir yapıyı yeniden değerlendirmek veya aynı işlev için yeni bir bina inşa etme ekonomisi alınacak kararı etkilemektedir (Johnson, 1998). Çünkü yeni bir bina için yoğun enerji ve maliyet gerekirken, eski bir yapıya yeni işlev verilmesinde yoğun emek gerektirmektedir (Karadayı Yenice ve Altınoluk, 2019). Aynı zamanda toplumsal gereksinme değişikliklerine karşı, yeni yap1 yapmak yerine yapısal yaşamlarını sürdüren anıt ve yapılara verilecek yeni işlev ile birlikte varlıkları sürdürülebilmektedir. Böylelikle de bir yandan kültürel ve tarihi devamlılık sağlamakta ve yapı israfı önlenerek korumanın ekonomik işlevinin varlığı gerçekleştirilmektedir (Yüce, 1981).

Kent içinde büyük önem arz eden yapıların zamanla değişmesi ya da yok edilmesi kentin fiziksel çevresinin farklılaşmasına yol açmaktadır. Bu durumda kentsel bellek de değişime uğramaktadır. Bu nedenle mimaride tarihi ve kültürel sürekliliğin devam edebilmesi için yeniden kullanım/ yeniden işlevlendirme olgusu önemli hale gelmektedir (Yalçınkaya ve Bal, 2019).

Tarihi yapılar yeni işlevle beraber değişen toplum ve ihtiyaçlara cevap vererek turizm ve kent kalkınmasına ekonomi yönünden de katkı sağlamaktadır. 1960'l1 yıllardan itibaren turizm, kendi değerlerine sahip olan kentlerin üzerinden getiri elde edilebildiği basit ve etkin yöntemlerden biri olmuştur (Kervankiran 2014; Eldek Güner 2017). Tarihi yapıların sahip olduğu tarihsel ve kültürel anlamlar topluma aktarılarak toplumda koruma bilincinin artırılması da sağlanabilmektedir. $\mathrm{Bu}$ nedenle tarihi yapılar sahip oldukları değerler üzerinden korunup müze işlevine dönüştürülmesi ile hem tarihi anlatıcı rolü üstlenebilmekte hem de kendisi bir sergi ürünü olarak insanlarla yeniden buluşabilmektedir. Bu sayede yapılar hem yeni fonksiyonlara cevap verebilecek hem de kente ekonomik ve kültürel katkı sağlayarak yeniden hayatın yaşayan bir parçası olabileceklerdir.

\section{Tarihi Yapılara Müze İşlevi Verilmesi}

Ülkemizde Osmanlı döneminden itibaren tarihi yapılara müze işlevinin verildiği görülmektedir. Bunun ilk örnekleri genellikle kiliseler olmuştur. Topkapı Sarayı ilk avlusundaki 6.yüzyıl kilisesi Hagia Eirene (Aya İrini) 1846 yılında Türk müzesinin ilk çekirdeğini oluşturan eserlerin sergilendiği yer olmuştur (Aydın ve Şahin, 2018). Cumhuriyet dönemindeki ilk örneklerden birisi de Topkapı Sarayı'dır. İşlevini kaybeden saray, Bakanlar Kurulu'nun 1 Nisan 1924 günlü kararı ile müzeye dönüştürülmüştür (Çal, 2009; Kervankiran 2014). Cumhuriyet döneminde işlevini yitirdiği için kullanılamayan diğer yapılar da müze olarak yeni işlev edinmişlerdir. Yapıların mimari özellikleri, iç mekânlarındaki süsleme ve motifleri sayesinde başka bir sergileme unsuruna ihtiyaç duymadan Anıt müze olarak yeni işlev verildiği de görülmüştür (Aydın ve Şahin, 2018).

Miras niteliği taşıyan bu yapıların müze işlevine uyarlanabilmesinde dikkate alınması gereken bazı noktalar olabilmekte ve tarihi binaların korunma yaklaşımları bu noktalardan birini oluşturmaktadır. Uluslararası tüzük ve kararların varlığı da miras niteliğindeki bu yapıların korunarak yeniden işlevlendirme sürecinde yol göstermektedir. Bu tüzük ve standartlar ise, kültürel mirasın korunması için uluslararası ölçütlere işaret etmektedir (Misırlısoy ve Günçe, 2016). ICOMOS'un 2003 yılında Victoria Şelaleri'nde yapılan 14. Genel Kurulu'nda kabul edilen "Mimari Mirasin Analizi, Korunması ve Strüktürel Restorasyonu İçin İlkeler" adindaki belgede yer alan 3.10 maddesinde, "Restorasyonda kullanılan malzemelerin özellikleri (öncelikle yeni malzemeler) ve mevcut olanlarla uyumu tam olarak araştırllmall, bilinmelidir. Istenmeyen yan etkileri önlemek amacıla, onarımda kullanilan malzemelerin uzun dönem etkileri araştırlmalıdır." 3.12. maddesinde ise, "Her müdahale mümkün olduğunca, strüktürün ilk tasarımına, yapım tekniğine ve tarihi değerine saygl göstermeli ve onun gelecekte de anlaşılmasını sağlayacak izleri korumaya özen göstermelidir" ifadeleri ile kültürel miras değerindeki yapılara yapılacak restorasyon çalışmaları ve müdahaleler hakkında tavsiyeler aktarılmaktadır (ICOMOS Tüzüğü, 2003).

1960'lı y1llardan itibaren turizm, kentlerin var olan değerleri üzerinden kolay bir şekilde gelir elde edebileceği yöntemlerden biri olmuştur. Müzeler ise turizmin ortaya çıkışından günümüze kadar insanlar için değerli olmuştur (Kervankiran, 2014). Yapılara müze işlevinin verilmesi ile kültürel değerlerin korunması ve aktarılmasında bir yol sunması ve tarihi mirasın taşıdığı bilgilerin tanımlanabilmesine olanak vermesi yönü ile tercih edilmektedir (Hussein, 2017). Bu yönüyle düşünüldüğünde müzelerin kullanıcılara sunduğu kültürel kimlik olgusu bu kimliği taşıyan mekânlarla birleştirildiğinde etkinlik gücü artırılabilmektedir. Son y1llarda işlev değerinin kaybetmiş veya mevcut işlevinin eski etkisi azalmış tarihi yapıların müzeleştirilmesi hem topluma kazandırılması hem de ekonomik gelir elde edilmesi amacıyla sıklıkla başvurulan bir yol olarak görülmektedir. (Eldek Güner, 2017).

Günümüzde hem daha fazla kullanıcıya ulaşabilme amaciyla hem de kentin turizm potansiyeline cevap verebilme adına kültür varlıklarının yeniden işlevlendirilmesinde müze işlevinin seçimine sıłça rastlanmaktadır. Bu yapılar, yerli ve yabancı turist çekerek kent ya da ülke için marka değerini arttırmaktadırlar. Müze olarak yeniden işlevlendirilen tarihi yapılar; hem kültür varlıklarının aktif şekilde korunabilmesini sağlamakta, hem de bulunduğu bölgenin turizm taleplerine cevap verebilmek adına önem arz etmektedirler (İslamoğlu, 2018).

Kayseri Lisesi'de sahip olduğu tarihsel ve mimari özelliklerinin yanı sıra kent için önemli bir bellek özelliği 
bulunmaktadır. Günümüzde okulun Milli Mücadele Müzesine dönüşmesindeki en önemli etkenlerden biri 19. yy sonunda eğitime başlayan okulun Kurtuluş Savaşı'ndan doğrudan etkilenmiş olmasıdır (Eldek Güner, 2017). Kurtuluş Savaşı'nda 1920-21 eğitim- öğretim yarıyılında son sınıf öğrencilerinin hiçbirini mezun verememesi üzerine toplumda önemli bir anı değerinin olması sebebiyle eğitim yapısı işlevindeki bu yapının Milli Mücadele Müzesi’ne dönüştürülmesine karar verilmiştir.

\section{MATERYAL VE YÖNTEM}

Çalışma iki aşamalı olarak ele alınmaktadır. Birinci aşamada tarihi yapıların yeniden işlevlendirilmesinin değerlendirilmesi ve Kayseri Lisesi'ne yönelik verilerin elde edilmesi amacıyla çalışmanın literatür araştırması yapılarak yazılı, çizili ve görsel kaynaklara ulaşılmıştır. Aynı zamanda Kayseri Kültür Varlıklarını Koruma Kurulu'ndan yap1 hakkındaki rapor ve çizimler elde edilmiştir. İkinci aşamada ise çalışma alanını oluşturan yapının işlev ve zamana bağlı değişimlerinin irdelendiği analiz çizelgeleri oluşturulup değerlendirilmiştir. Analiz çizelgelerinin oluşturulmasında yapının yeniden işlevlendirme öncesi ve sonrası görsellerine ve KKVKK arşivine başvurularak yapının planlarına ulaşılmıştır. Lise ve müze işlevine ait planlar üzerinden işlev değişikliği sonucunda iç mekânlarda ve yapıda meydana gelen değişimler tespit edilmeye çalışılarak yapının tarihi dokusu üzerinde bir değişim olup olmadığ 1 değerlendirilmektedir. $\mathrm{Bu}$ kapsamda yapının işlevsel değişimi sonucu ortaya çıkan yeni mekân ihtiyaçları yapının lise işlevi ve müze işlevine ait planlar üzerinden eylem alanları işlev gruplarına göre renklendirme yolu ile taranarak, mekânlardaki işlev değişikleri ifade edilmektedir. Ardından yeni işlev sonucu yapı elemanları ve mekânlar üzerinde yapılan fonksiyonel değişiklikler yapıya eklenen alanlar ve değişen alanlar başlıkları altında plan üzerinden numaralandırılarak aktarılmaktadır.

\section{ARAŞTIRMA BULGULARI}

Çalışmaya ilişkin bulgular; çalışma alanının tanıtılması ve Kayseri Lisesi'nin tarihçesi ve mimari özelliklerinin aktarılmasının ardından lisenin işlev değişikliği sonucu oluşan ve zamana bağlı olarak meydana gelen değişimlerine ilişkin oluşturulan analiz çizelgelerine yönelik bulgular şeklinde ele alınmaktadır.

\section{Çalışma Alanı: Kayseri, Kayseri Lisesi (Taş Mektep)}

Anadolu'da ilk kez imparatorluk kurmaya çalışan Hitit İmparatorluğuna dâhil olan Kayseri, Kayseri'nin şuan ki konumunun $23 \mathrm{~km}$. kuzeydoğusunda Kaniş ismi ile kurulmuştur. Kaniş şehrinin önemini yitirdiği dönemde şehir, bugünkü Kayseri konumunun $2 \mathrm{~km}$. güneyine Mazaca ismi ile kurulmuștur (Eldem, 1982). Tarih boyunca birçok uygarlığın hâkimiyeti altında olmuştur. Fatih Sultan Mehmet zamanında Osmanlı topraklarına katılmasıyla beraber şehir daha hızlı bir şekilde yapılaşmaya başlamıştır ve günümüzdeki önemli tarihi yapıların birçoğu bu dönemlerde yapılmıştır. Türkiye Cumhuriyeti'nin kuruluşu ile birlikte de il olarak Kayseri adını almıştır (Göde,1991). Kayseri, yaklaşık altı bin yıla uzanan tarihiyle, Eski Tunç, Hitit, Frig, Helenistik, Roma Bizans, Selçuklu, Osmanlı ve Cumhuriyet dönemlerine ait eserlerden oluşan zengin bir kültürel mirasa sahiptir (Kayseri Büyükşehir Belediyesi, 2014).

Çalışma alanı olarak belirlenen tarihi yapı da Osmanlı Geç-Dönem tarihi yapıları içerisinde yer almaktadır. Lise dengi okul olarak yaptırılan yapı o zamanki ismi ile idadi “Derece-i Üla Mekteb-i Mülkiye İdadi'si” adıyla kurulmuş ve yapının 1904 yılında inşa edildiği kabul edilmektedir. Yapı, iki katlı düzgün kesme taştan yapılmış çatısı kırma çat1 ve Marsilya kiremitleri ile örtülüdür (Özmerdivenli, 1997; Kültür ve Turizm Müdürlüğü, 2009). Kayseri Lisesi yapım yılından 2013 yılına kadar orijinal işlevi olan eğitim yapısı olarak kullanılmıştır. 2013 yılında ise lisenin hem tarihi hem de anısal değerinden dolayı Milli Mücadele Müzesi'ne dönüştürülmesine karar verilerek restorasyon çalışmalarına başlanmıştır. Bu kapsamda Kayseri Lisesi mevcut işlevinin yerinde gözlem ve fotoğrafları, eski işlevin ise Kültür Varlıklarını Koruma Kurulundan alınan çizim ve fotoğrafları doğrultusunda analizler yapılarak irdelenmiştir.

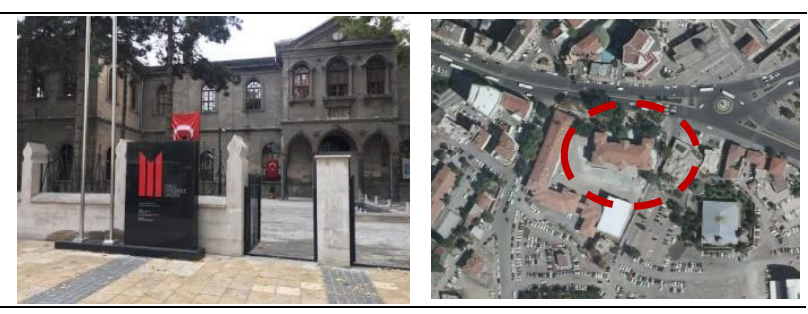

Şekil 1. Milli Mücadele Müzesi ve Müzenin konumu

\section{Yapının Tarihçesi ve Mimari Özellikleri}

Kayseri’nin 100 yıllık geçmişine tanıklık etmiş olan Kayseri Lisesi, Geç-Osmanlı Dönemi’nde kurulmuş olan önemli bir eğitim kurumu olarak kentte öne çıkmaktadır (Işık, 2010). Kayseri Lisesi binası; Kayseri ili, Melikgazi ilçesi, Kiçikapı Mahallesi'nde, bugün ayakta olan Surp Astvastzaddin (Meryem Ana) Ermeni Kilise'sinin güneydoğusunda bulunmaktadır. Günümüzde, tarihi değeri ve anıtsal görünümü ile kent için dikkat çeken bir konumda bulunmaktadır. Kayseri Lisesi, 'Gayrimenkul Eski Eserler ve Anıtlar Yüksek Kurulu' tarafindan tescil edilerek korunma altına alınmıştır (Kültür ve Turizm Müdürlüğü, 2009).

Kayseri idadisinin (lisesinin) inşasına, Ankara Valisi Sırrı Paşa'nın isteği üzerine kurul komisyonunca M.1884 yılında başlanmasına karar verilmiştir (Sağıroğlu Arslan, 2010). Kayseri İdadi'si 13 Eylül 1893 tarihinde “Derece-i Ula Mektebi İdadisi'" ismi ile açılmıştır (Erkiletlioğlu, 2006). Lisede öğretim ise ilk kez Seyfullah Efendi Konağı'nda başlamıştır. Bugünkü Kayseri Lisesi binası birinci katı H. 1322 M. 1904 yılında şuan ki yerine inşa edilmiştir. (Çayırdağ, 2001). Lisenin ikinci katı ise 19151916 yılında tamamlanmış ve ismi 'Sultani' olmuştur. (Çayırdağ, 1997). 1927 yılında ise Kayseri Lisesi ismini almıştır (Yeğen, 1993).

Okulun iki katı da öğretime yetemeyecek duruma gelince, 1927 yılında yakınında bulunan Cizvit papazlarına ait olan iki bina liseye eklenmiştir. Kayseri Lisesi'ne belirli dönemlerde eklenerek eğitim yapısı işlevinde son halini almıştır (Şekil 2). Yeni bina olarak adlandırılan bina 195657 'de (bugünkü yapının batı cephesine eklenen taş bina), pansiyon binası 1965-66'da, spor salonu ve konferans 
salonu binası 1976-77'de yapılmıştır (Özmerdivenli, 1997).

Yapının bütün cephelerinde yapıda bulunan düz yüzeyli kalın bir silme mevcuttur. Bu silme ile yapının zemin kat ve bodrum katı birbirinden ayırt edilmiş ve binanın alt sınırı belirlenmiştir. Yapıda, duvar yüzeylerinden hafifçe dışarı taşırılmış dikdörtgen planlı duvar payeleri (plastırlar) bulunmaktadır. Yapının cephelerini dikey olarak bölen duvar payeleri, yapının cephelerini hareketlendiren cephe elemanları olarak göze çarpmaktadır. Yapının köşelerine yerleştirilen mekânların kütlesel olarak dişarıya taşırılmış olması ile cephe hareketlilik kazanmıştır. Yalın olmasına rağmen anıtsal bir cephe düzenine sahip olan ve Neoklasik özellikler taşıyan yapının, anıtsal boyutlardaki pencereleri öne çıkmaktadır (Sağıroğlu Arslan, 2010).

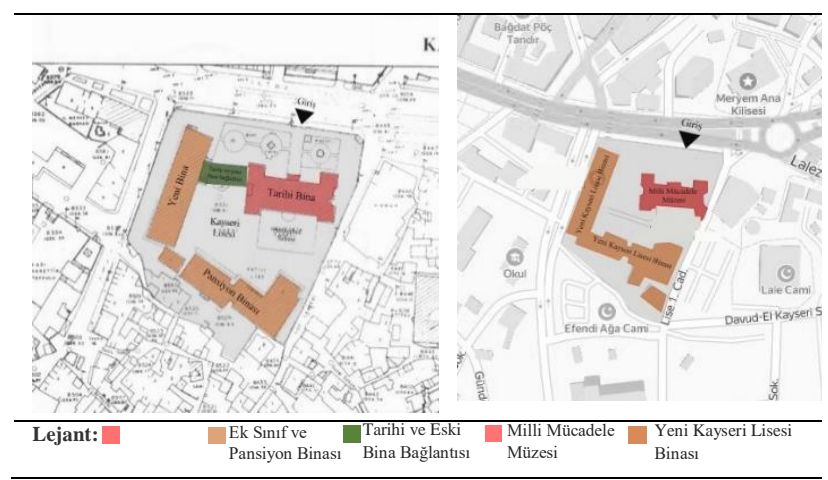

Şekil 2. Kayseri Lisesi vaziyet planı (Özmerdivenli, 1997) ve Milli Mücadele Müzesi konumu

Kayseri Lisesi'nin A Blok olarak bilinen tarihi binas 2012 yılında yapılan görüşmeler sonucunda müzeye dönüştürülmene karar verilmiş ve lise Büyükşehir Belediyesi'ne devredilmiştir. Dönüşüm sürecinde derslik olarak kullanılan pansiyon binası, konferans salonu ve spor salonu yıkılarak yerine tarihi yapıya uygun 10 derslik yeni ek bina yapılmıştır. Bu yeni ek bina olan Kayseri Lisesi 2013 yılında hizmet vermeye başlamıştır (MEB, Kayseri Lisesi, 2018). Tarihi yapı ise yapım yılından 2013 yılına kadar özgün işlevi ile kullanılmış olup, 2013 yılında Milli Mücadele Müzesi olarak işlevlendirilmesi kararıyla restorasyon çalışmalarına başlanmıştır. Literatür taramalarında yapının lise işlevinde kullanımındayken yapılan eklemeler, müzeye dönüşüm çalışmalarında kaldırılarak yapı ilk günkü haline dönüştürülmeye çalışılmıştır. Lise işlevi ve müze işlevindeki işlev değişikliği ve yeni işleve yönelik mekansal ihtiyaçlar ve düzenlemeler sonucu oluşan değişimler esas alınarak analiz çizelgeleri hazırlanmıştır.

\section{Yapının Değişim Süreci}

Kayseri Lisesi'ne ve Milli Mücadele Müzesi'ne ait bilgilerin yer aldığı kimlik kartları ile yapının yeniden işlevlendirilmesi sonucunda plan, cephe ve iç mekanlar üzerindeki değişimler aktarılmıştır.

Aşağıdaki çizelgede yer alan yapıya ait fotoğraf ve bilgiler 1904-2013 yılları arasındaki kullanım durumunu ifade etmektedir. $\mathrm{Bu}$ yıllar arasında yap1 lise işlevinde kullanılmış ve çizelgede yapının lise işlevine ait kimlik bilgileri, kat planlarına yer verilmiştir. Yapının kimlik bilgileri, adres, yapım tarihi, mimari dönem/tarzı ve mimari özelliğinden oluşmaktadır. Kat planlarında ise bodrum kat, zemin kat ve birinci kat planlarına yer verilmiştir (Çizelge 1).

Çizelge 1: Kayseri Lisesi (1904-2013) kimlik kartı (Görsel ve plan Sağıroğlu Arslan, 2014)

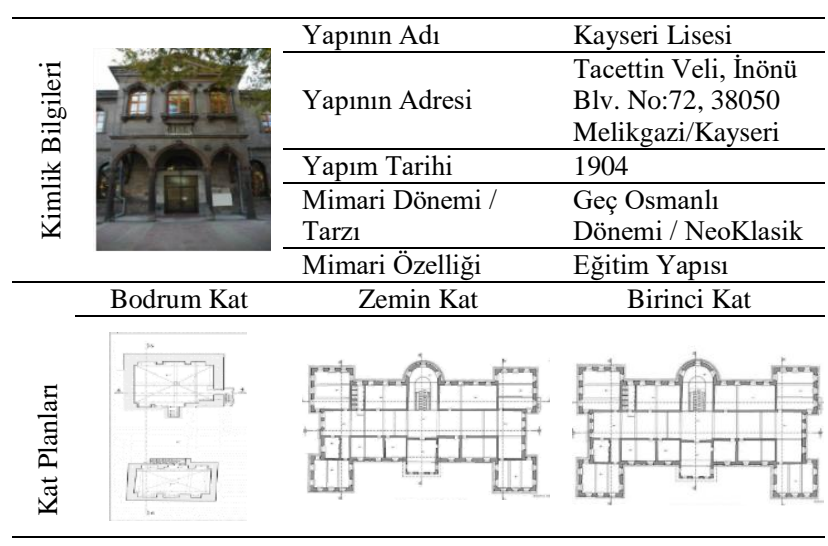

Çizelge 2'de Kayseri Lisesi'nin lise işlevine ait cephe ve iç mekân görsellerine yer verilmiştir. Cephe görselleri yapının kuzey, güney, doğu ve batı yönlerinden verilmiştir. Son olarak da yapının iç mekânlarından detaylı görselleri verilerek lise işlevindeki kullanımı aktarılmıştır (Çizelge 2).

Çizelge 2: Kayseri Lisesi cephe ve iç mekân görselleri (Görseller Sağıroğlu Arslan, 2014)
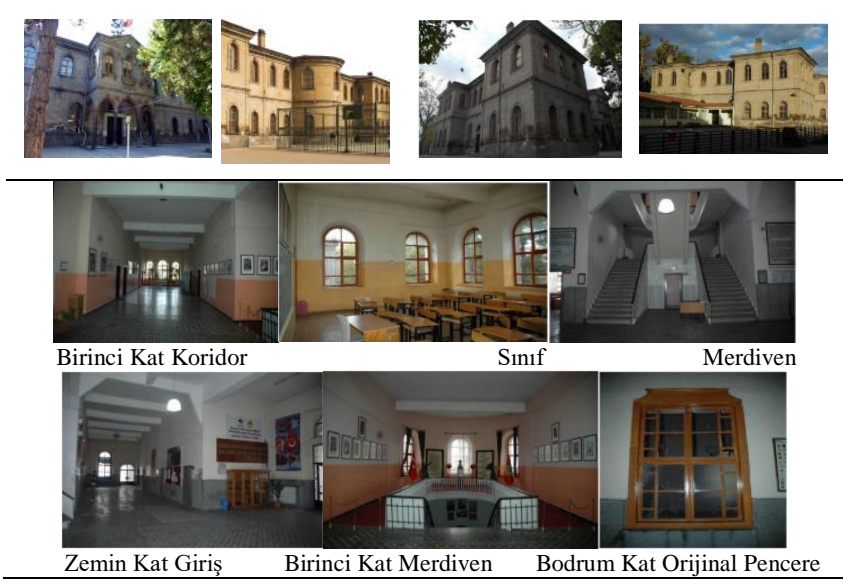

3. çizelgede 2013 yılında restorasyonuna başlanıp 2016 yılında müze işlevi ile kullanıma açılan yapının yeni işlevine ait kimlik bilgileri, plan çizimlerine yer verilmiştir (Çizelge 3).

4. çizelgede ise müze işlevli yapının yerinde tespit yolu ile ulaşılan cephe ve iç mekân görselleri aktarılmıştır (Çizelge 4). Yap1 müze işlevine dönüşümle beraber yeni işlev ihtiyaçları mekânların kullanımında farklılaşmalara neden olmuştur. Müzenin zemin katı sergi alanlarından oluşarak birinci kat idari birimlere ayrılmıştır. Ziyaretçilerin bu kata erişimi olmadığı için bu katta bulunan mekânların görsellerine de erişilememiştir. $\mathrm{Bu}$ nedenle KKVKK'da yapıya ait belgeler incelenerek birinci katta bulunan makam odasının görseli kullanılmıştır. Bunun dışında 
merdiven sahanlığının görseline de sanal müze ortamından ulaşılmıştır (Şekil 3).

Çizelge 3: Milli Mücadele Müzesi (2016-) kimlik kartı (Kişisel Arşiv ve KKVKK Arşivi)

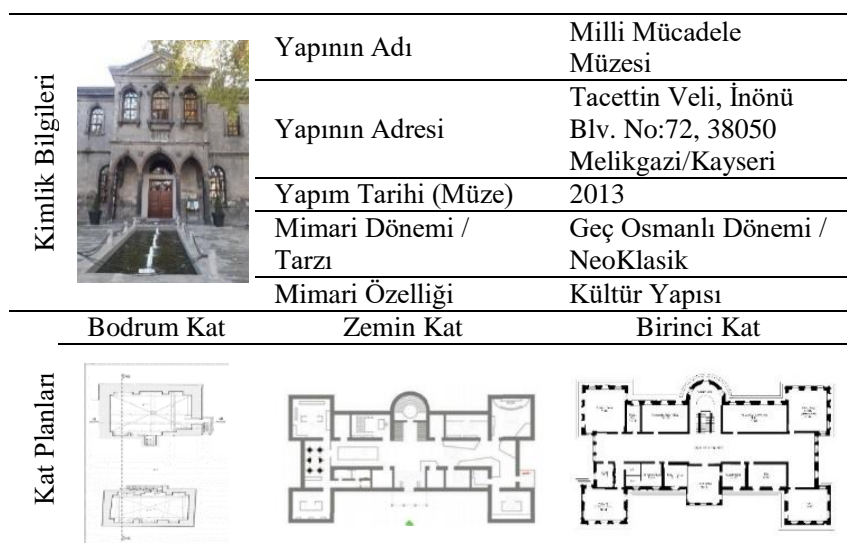

Çizelge 4: Milli Mücadele Müzesi cephe ve iç mekân görselleri (Kişisel Arşiv)

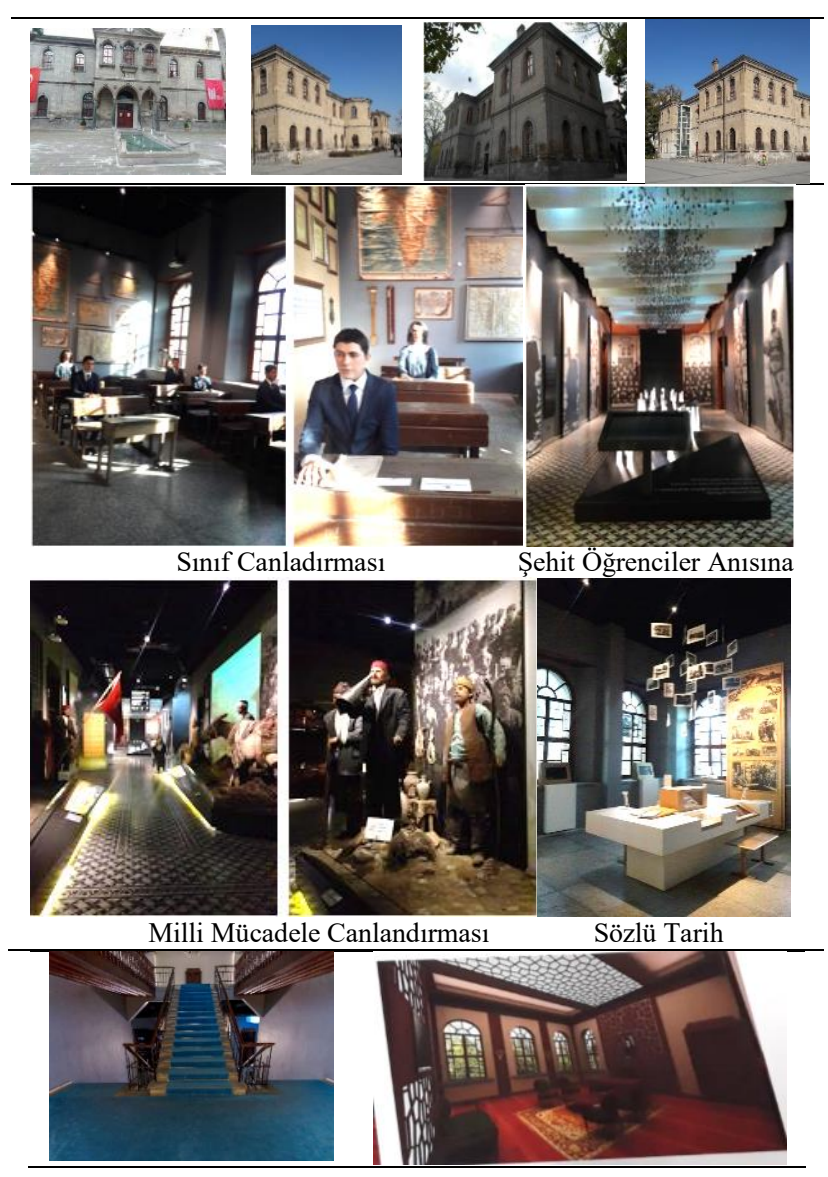

Şekil 3. Kayseri Milli Mücadele Müzesi merdiven ara kat (URL-4) ve makam odası renderı (KKVKK Arşivi)

\section{Yeni İşlev Gereği Yapılan Mekansal İhtiyaçlar ve Müdahaleler}

Kayseri Lisesi, yeniden işlevlendirme sonucu oluşan işlev değişikliği gereği ortaya çıkan mekânsal ihtiyaçlar ve müdahaleler kapsamında değişimler yaşamıştır. Yaşanan bu değişimler yapının ana strüktürüne zarar vermeden gerçekleştirilmeye çalışılarak günümüze kadar gelebilmesi sağlanmıştır.

Çizelge 5: Kayseri Lisesi - Milli Mücadele Müzesi mekânsal analiz tablosu

\begin{tabular}{|c|c|c|}
\hline Kat & Özgün İșlev & Mevcut İşlev \\
\hline $\begin{array}{l}\text { Bodrum } \\
\text { Kat }\end{array}$ & Depo & Depo, Teknik Oda \\
\hline $\begin{array}{l}\text { Zemin } \\
\text { Kat }\end{array}$ & $\begin{array}{lr}\text { Sinıflar, } & \text { Müdür } \\
\text { Yard. } & \text { Odas1, Öğrt. } \\
\text { Odas1, } & \text { Rehberlik } \\
\text { Odas1, } & \text { Revir, } \\
\text { Teknik } & \text { Oda, } \\
\text { Hacim } & \end{array}$ & $\begin{array}{l}\text { Giriş, Danışma, Güvenlik, } \\
\text { Hediyelik Eşya Satım } \\
\text { Alanı, Sergi Alanı, İdari } \\
\text { Birimler, } \\
\text { Birim(Kafe-Atölye), Islak } \\
\text { Hacim }\end{array}$ \\
\hline $\begin{array}{l}\text { Birinci } \\
\text { Kat }\end{array}$ & $\begin{array}{lr}\text { Sinıflar, } & \text { Müdür } \\
\text { Odas1, } & \text { Zümre } \\
\text { Odas1, } & \text { Bilgisayar } \\
\text { Lab., Müze, Islak } \\
\text { Hacim }\end{array}$ & $\begin{array}{l}\text { İdari Birimler, Toplant1 } \\
\text { Odaları, Konferans Odası, } \\
\text { Personel Odası, } \\
\text { Kütüphane, Müze, Teknik } \\
\text { Oda, Geçici Sergi, Islak } \\
\text { Hacimler }\end{array}$ \\
\hline
\end{tabular}

Ek Yap1 Sinıf, Pansiyon,

Konferans Salonu

Kayseri Lisesi’nin Milli Mücadele Müzesi'ne dönüşümündeki işlev değişikliği ile beraber yapının mevcut işlevindeki ihtiyaçlara yönelik kullanılan alanlar yeni işlevle beraber ortaya çıkan yeni ihtiyaçlara uygun olarak dönüştürülmüştür. Çizelge 5'e baktığımızda zemin katın lise işlevinde sınıflar, müdür yardımcı odası, rehberlik odas1, revir, teknik oda ve sslak hacimlerden oluşturulduğu görülürken müzeye dönüşümle beraber zemin kat danışma, güvenlik, hediyelik eşya satım alanı, sergileme alanları, müze müdürü ve personel odası, kafeterya ve ıslak hacimlerden oluşmaktadır. Birinci kat ise, lise işlevinde yine sınıflar, müdür odası, bilgisayar laboratuvarı, müze ve islak hacimlerden oluşmaktaydi. Yeni işlevle birlikte birinci kat daha çok idari birimlerin bulunduğu ve ziyaretçilere kapalı olan bir alan olarak tasarlanmıştır. Bu katta makam odası, toplantı odaları, konferans ve çok amaçlı salon, kütüphane, geçici sergi alanı, müzede kullanılan birimlerin tamiri veya depolanması için alan, personel odası, teknik oda ve sslak hacimlerden oluşmaktadır. Yapı lise işlevinde kullanıldığında ortaya çıkan ihtiyaçlarla yapı yeterli gelmemiş ve yapıya ek yapılar yapılmıştır. Yeni işlevle birlikte bu ek yapılar yapıdan ayrılmıştır. Müze işlevinde de yapıya herhangi bir ek yapı eklenmemiştir (Çizelge 5).

Yapının işlev değişimi ile birlikte ortaya çıkan değişimlerin anlatıldığı 6.çizelgede mekânların eski ve yeni işlev doğrultusunda kullanımı planlar üzerinde yapılan renklendirmeler ile verilmiştir. Renklendirme yapılırken benzer işlevlere belli gruplamalar yapılarak renklendirme basitleştirilmiştir. Bu renklendirmelerle idari birimler, öğrenim birimleri, sergi alanları, kafeterya, sirkülasyon alanları ve destek birimler her iki işlevin 
planlarında belirtilmiştir. Lise işlevine ait birinci kat planında herhangi bir renklendirme yapılmayan iki mekân bulunmaktadır. Bu mekânların hangi işlevde kullanıldığı bilgisine ulaşılamamıştır. (Çizelge 6).

Çizelge 6: Kayseri Lisesi işlevsel değişim analizi
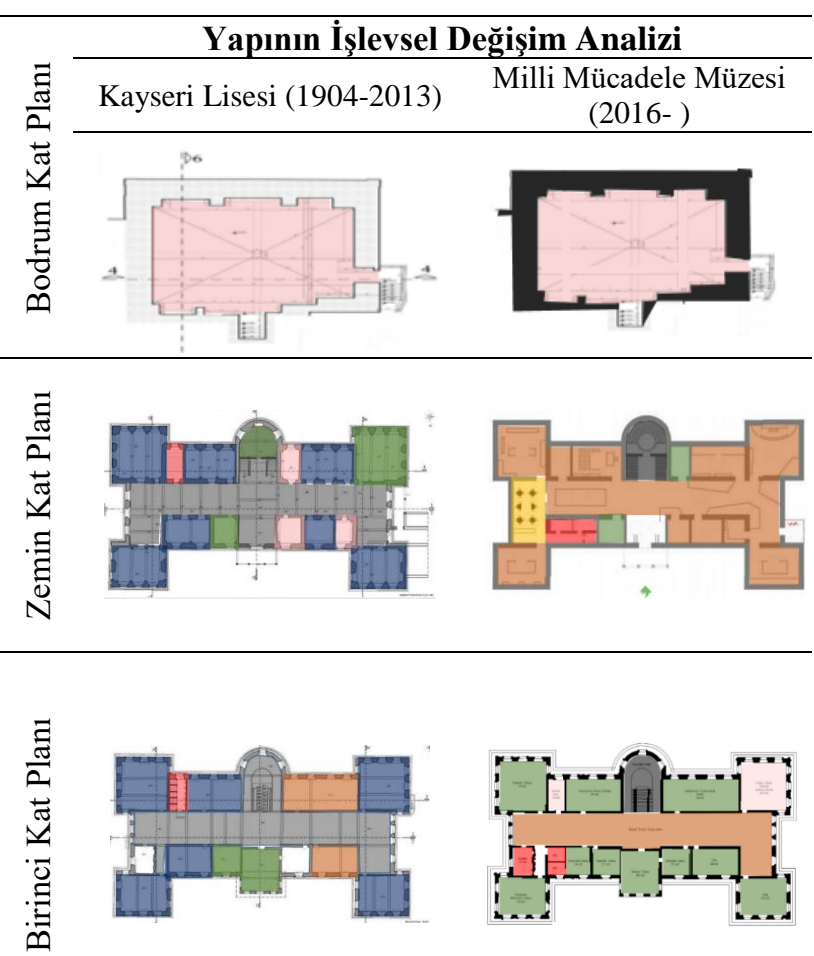

İdari Birimler Öğrenim Birimleri Sergi Birimleri Kafeterya Sirkülasyon Alanları Destek Birimler

Yapıda zaman içinde meydana gelen değișimlerin anlatıldığı çizelge 7'de 1904-2013 yılları ve 2016günümüz yıllarında ki kullanımı fiziksel ve fonksiyonel değişimler olarak verilmiştir. Fiziksel değişimlerde yapının planları üzerinde renklendirme ve işaretleme ile yapıya zaman içinde eklenen alanlar mavi renk, çıkarılan alanlar kırmızı renk ve boyutsal değişimlerinin olduğu alanlar ise çift yönlü ok ile işaretlenmiştir. Fonksiyonel değişimlerde ise zaman içinde yapıya eklenen ve değişen alanlar plan üzerine yapılan numaralandırma ile belirtilmiştir (Çizelge 7).

Tüm analizlere baktığımızda Kayseri Lisesi'nin Milli Mücadele Müzesi'ne dönüştürülmesinde yapının tarihsel belge niteliğinin ve kent için ifade ettiği anlamın korunması hedeflenmiştir. Alınan yeniden işlevlendirme kararı sonucunda yapıya zaman içinde olan ihtiyaçlar sonucu eklenen tüm ek yapılar kaldırılarak yapı ilk inşa edildiğindeki haline dönüştürülmüştür. Yapı dış cephe mimarisi zaman içinde büyük hasarlar almadan özgün malzeme ve dokusu ile gelmeyi başarmıştır. İç mekân döşeme, kap1 ve pencereleri ise günümüze kadar gelememiş ve restorasyon çalışmalarında yapının özgün pencere kasalarının benzerleri yapılmış sadece bodrum katta orijinal hali ile günümüze gelen pencere korunmuştur. Yapının müze işlevine dönüşmesi ile kullanılmayan kapılar sergi üniteleri ile kapılara zarar vermeyecek ve temas etmeyecek şekilde kapatılmıştır. Yeni işlev gereği ortaya çıkan ihtiyaçlar sonucunda ıslak hacimlerin yerinin değiştirilmesi ile mevcut iç mekân kapıların aynısı yeni mekân yerleşimlerine eklenmiştir. Sergi panoları ise kendi kendini taşıyabilecek şekilde tasarlanarak duvarlara minimum temas gözetilerek zorunlu olmadığı sürece duvarlar taşıyıcı olarak kullanılmamıştır. İç mekânda alınan kararlar mekân strüktürüne minimum müdahale çerçevesinde ilerleyerek olası ihtimallerde geriye dönüşe imkân sağlayabilmektedir.

Çizelge 7: Yeni işlev sonucu yapıda meydana gelen değişimlerin analizi
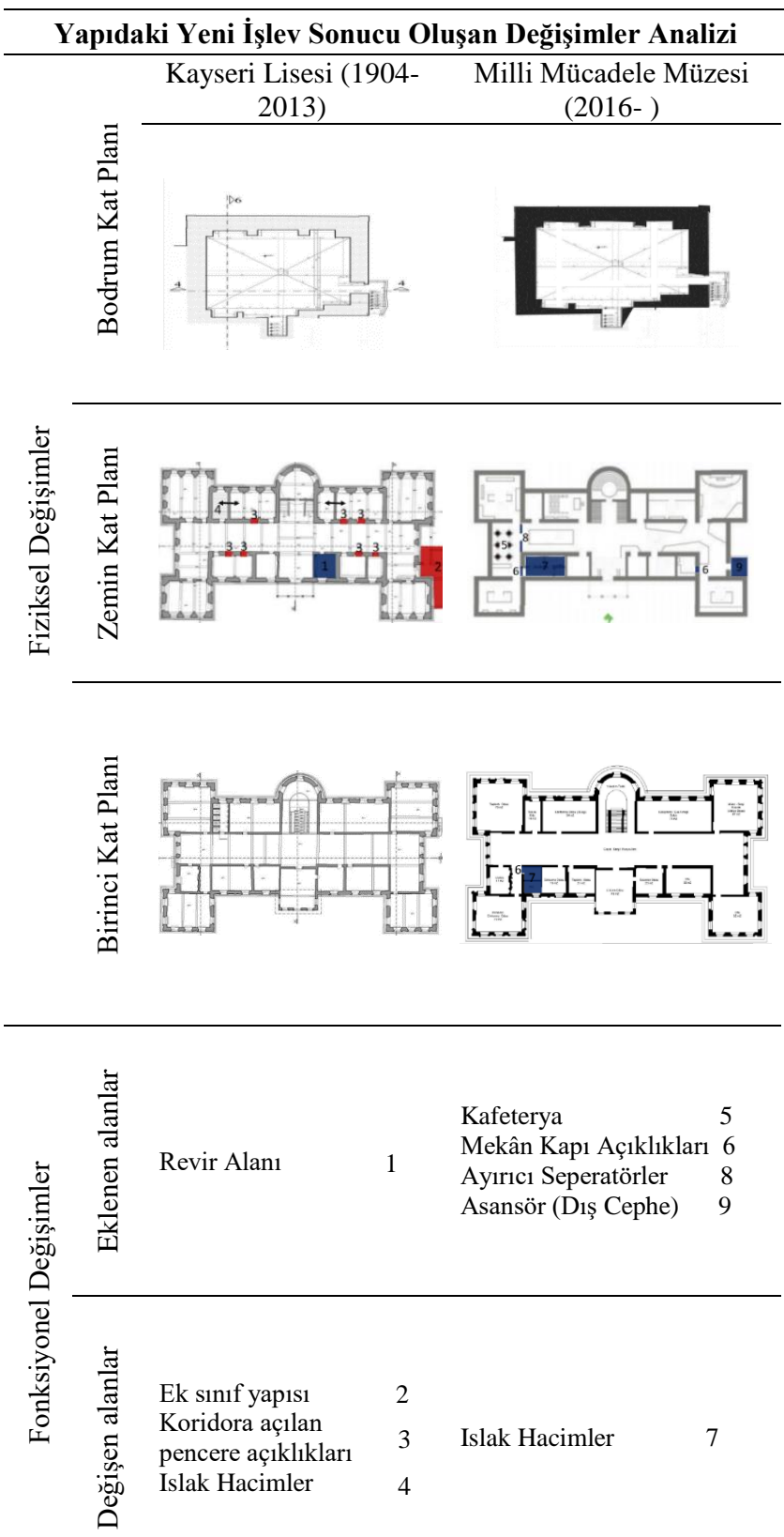

Lejant $\square$ Çıkarılan Alanlar $\square$ Eklenen Alanlar $\longleftrightarrow$ Boyutsal Değişim 


\section{DEĞERLENDIRME ve SONUÇ}

Kültürün ve tarihin en okunabilir taşıyıcıları olan tarihi eserlerin geleceğe aktarılabilmesi için günümüz ihtiyaç ve değişimlerine en uygun şekilde cevap verebilecek yeni işlevler verilmesi izlenebilecek bir yol olarak gösterilebilir. Bu bağlamda tarihi yapılara yapılan yeniden işlevlendirme ile yapının sahip olduğu değerli izlerin bilgilerin aktarılması sağlanmaktadır. Çalışmada ele alınan Kayseri Lisesi Geç Osmanlı Dönemi'ne ait olan sayılı örneklerden birisidir. 1904 yılında lise işlevi ile kullanıma başlamış ve 2013'e kadar mevcut işlevini koruyarak kullanılmıştır. Fakat yıllar içinde yapının yapısal ve mekânsal kurgusunda herhangi bir değişiklik olmasa da yapıda kullanılan orijinal iç mekân malzemeleri, kapı ve pencerelerin çoğu günümüze ulaşamamıştır. Kayseri Lisesi yapım yılı 1904 yılından günümüze kadar yapısal ve mekânsal özelliklerinin birçoğunu korumuştur. Günümüze kadar orijinal haliyle gelemeyen kısımlar genellikle yapıda kullanılan malzemeler, kap1 ve pencereler olmuştur. Malzemelerin dişında oda büyüklükleri de ihtiyaçlar doğrultusunda değiştirilmiştir. Bu boyutsal değişiklikler genellikle zemin kat güney ve kuzey cephesindeki odalarda görülmüştür. Bu odalardan birisinin 1slak hacim olarak kullanılması ile mekân boyutsal olarak küçültülmüş yanındaki mekân ise büyütülmüştür. Müze işlevine dönüş ile birlikte küçültülen veya ikiye bölünen mekânlar orijinal boyutlarına dönüştürülmemiştir. Zemin kattaki odalara ait tüm kapılar onarımlarla yenilenmiştir. Fakat orijinal hali maalesef günümüze ulaşılamamıştır. Aynı şekilde bütün odaların tabanları orijinal olmayan lambri parkelerle kaplanmıştır. Müzeye dönüşümle beraber de hol seramik karo kaplanmış ve odalar ise mozaik beton dökülerek değiştirilmiştir. Günümüze kadar orijinal hali ile gelebilen tek yer merdivenin ahşap konstrüksiyonu olmuştur. Müzeye dönüşümle beraber hala merdiven orijinal hali ile kullanılmakta ama merdivenler müze ziyaretçilerinin kullanımına kapatılmıştır. Sadece müzenin idari yöneticileri tarafından kullanabilmektedir. Yapının müze işlevine dönüşmesiyle beraber zemin katta bulunan ve koridor alanına açılan pencereler sergileme panoları ile kapatılmıştır. Sergileme panoları pencerelere herhangi bir zarar vermemiş ve belli bir mesafe uzaklıkla kapatılarak pencerelere müdahale edilmemiştir. Aynı şekilde sergi alanı ve kafeterya kısmını ayırmak için sergi görevi de üstlenen seperatörler kullanılmıştır. Lise işlevinde iken güney doğu cephesindeki kare çıkması şeklindeki odanın yanında bulunan erkek wc müze işlevinde il eğitim tarihi müzesi olarak dönüştürülmüştür. Yine müze işlevine göre, 1slak hacim kuzey batı cephesindeki kare çıkması şeklindeki odanın yanında bulunan mekâna tasarlanmıştır. Bunun sonucunda, 1slak hacim kapısının yeri değiştirilerek kafeterya alanına bakan duvara yeni kapı açıklığı açılmış ve sergi alanı ile olan bağlantısı koparılmıştır. Zemin kattaki ıslak hacim mekânı ile aynı kesitte yer alacak şekilde birinci kat için de yeniden düzenlenmiştir. Tüm bu değişimlerin sebebi olarak birbirinden ayrı iki işlevin olması ve her iki işlevinde birbirinden farklı ihtiyaçlarının bulunması olarak düşünülmektedir.

Tarihi yapılarda yapının işlevinin eskimesi ve günün ihtiyaçlarına cevap verememesi üzerine zaman içinde toplumdan soyutlaşmaya ve önemini yitirmeye başlar. Bunu önlemek ve tarihi yapıları topluma yeniden kazandırmak amacıyla yeniden işlevlendirme yapılmaktadır. Fakat Kayseri Lisesi için işlev eskimesi ya da günün ihtiyaçlarına cevap verememesi gibi bir durum söz konusu değildir. Çünkü lise 2013 yılına kadar değerini kaybetmeden yaşayabilmiştir. Kayseri Lisesi'nin müze işlevine dönüştürülmesindeki amacın yapının korunması için yapıldığg düşünülmektedir. Lise işlevinde kullanımında tarihsel anlatıcı rolünün bilincinde olunmadığı ve bu bilincin kaybedilmesinin istenmemesi sebebiyle lise Milli Mücadele Müzesi'ne dönüştürülmüştür.

\section{BILGí}

Makalede kullanılan fotoğraflar ve belgeler için gerekli izinler alınmıştır.

\section{KAYNAKÇA}

Ahunbay, Z. (2009). Tarihi Çevre Koruma ve Restorasyon. İstanbul: Yem Yayınları.

Ahunbay, Z. (2013). 2013'ün tartışmalı yeniden kullanım ve ihyaları, Mimarlı Dergisi, 354. http://www.mimarlikdergisi.com/index.cfm?sayfa=mi marlik\&DergiSayi $=388 \&$ RecID $=3322$ [Erişim Tarihi: 28.04.2021]

Altınoluk, Ü. (1991) Özgün İşlevini Tamamen Yitiren yada İşlevsel Olarak Eskiyen Yapıların Yeniden Kullanımı, Tasarım Dergisi, Say1 14.

Altınoluk, Ü. (1998). Binaların yeniden kullanımı. İstanbul: Yapı Endüstri Merkezi Yayınlar.

Aras, A. (2020). On Sustainability of Religious Buildings Ending Usage: Bursa Isabey Mosque. In H. A. Nia., (Ed.), New Approaches in Contemporary Architecture and Urbanism, 168-176. Antalya: Cinius Yayınları.

Arslantaş, F. (2009). 20.yüzyıl'ın ilk yarısında Kayseri'de kamu yapıları (Yayınlanmamış yüksek lisans tezi). Marmara Üniversitesi, İstanbul.

Aydın, A. ve Şahin, Ö. (2018). Tarihi yapıların yeniden işlevlendirilmesi: Isparta Aya İshotya (Yorgi) Kilisesi'nin Gül Müzesi’ne dönüșümü. TÜBA-KED, (17), 63-75. doi:10.22520/tubaked.2018.17.004

Aydın, D. ve Yaldız, E. (2010). Yeniden Kullanıma adaptasyonda bina performansinın kullanıcılar üzerinden değerlendirilmesi. METU JFA, 27(1), 1-22.

Cantacuzino, S. (1989). Re-Architecture Old Buildings/New Uses, New York: Abbeville Press.

Çal, H. (2009). Osmanlı'dan Günümüze Türkiye'de Müzeler, Türkiye Araştırmalarl Literatür Dergisi. 7(14), 315-333.

Çayırdağ, M. (1997). Kayseri'de Sultan II. Abdülhamit Dönemi Bina ve Kitabeleri, I. Kayseri ve Yöresi Tarih Sempozyumu Bildirileri (11-12 Nisan 1996), Kayseri.

Çayırdağ, M. (2001). Kayseri Tarihi Araştırmalart, Kayseri: Kayseri Büyükşehir Belediyesi. 
Edhem (Eldem), H. (1982). Kayseri Şehri, (Haz.: Kemal Göde), Ankara: Kültür ve Turizm Bakanlığı Yayınları.

Eldek Güner, H. (2017). Liseden müzeye, eğitimden tüketime; Kayseri Lisesi'nin Millî Mücadele Müzesi'ne dönüşümü. TÜBA-KED, (16), 67-87. doi:10.22520/tubaked.2017.16.003

Eraybat, F.G. (2011). Tarihi konaklama yapılarının doğuşu, gelişimi ve günümüzde çağdaş işlevle değerlendirilmesi: Edirne Rüstempaşa Kervansarayı örneği (Yayımlanmamış yüksek lisans tezi). Trakya Üniversitesi, Edirne.

Erder, C. (1977). Venedik Tüzüğü tarihi bir anıt gibi korunmalıdır, O.D.T.Ü Mimarlık Fakültesi Dergisi, 3(2), 167-190.

Erkiletlioğlu, H. (2006). Geniş kayseri tarihi, Kayseri: Bel-Sin Eğitim Yayınları.

Feilden, B. M. (1982). Conservation of Historic Buildings, London: Butterworth Scientific, 1982.

Gazi, A. ve Boduroğlu, E. (2015). İşlev değişikliğinin tarihi yapılar üzerine etkileri Alsancak Levanten evleri örneği, Megaron 10 (1), 57-69. doi: 10.5505/megaron.2015.86570

Göde, K. (1991). Tarih İçinde Kayseri, Kayseri: Erciyes Üniversitesi Yayını.

Gül Asatekin, N. (2004). Kültür ve doğa varlıklarımız neyi, niçin, nasıl korumalıyız?, Ankara: T.C. Kültür ve Turizm Bakanlığı DÖSIMMM Basımevi

Hasol, D. (2005). Ansiklopedik Mimarlık Sözlüğü, İstanbul: Yapı Endüstri Merkezi Yayınları

Hussein, N. (2017). Adaptive reuse of the industrial building: a case of energy museum in Sanatistanbul, Turkey, Journal of Contemporary Urban Affairs, 1(1), 24-34.

ICOMOS.

(2003). http://www.icomos.org.tr/Dosyalar/ICOMOSTR tr00 33791001536913477.pdf [Erişim Tarihi: 30.04.2021].

İslamoğlu Ö, (2018) Tarihi Yapıların Yeniden Kullanılmasında Yapı-İşlev Uyumu: Rize Müzesi Örneği, Journal of History Culture and Art Research, 7(5), 510-523. doi:http://dx.doi.org/10.7596/taksad.v7i5.1573

Johnson, A. (1988). Converting Old Buildings: Homes From Barns, Churches, Warehouses, Stations, Mills. UK: David \& Charles.

Karadayı Yenice, T. ve Altınoluk, Ü. (2019). New uses for old buildings: the case of 'Soğukçeşme' Street, İstanbul, Turkey, ICONARP International Journal of Architecture \& Planning, 7(1): 314-329.

Kaşlı, B. (2009). İstanbul'da Yeniden işlevlendirilen korumaya değer endüstri yapıları ve iç mekân müdahaleleri: Santral İstanbul örneği (Yayımlanmamış yüksek lisans tezi). İstanbul Teknik Üniversitesi, İstanbul.
Kayseri Büyükşehir Belediyesi (2014). Kültür yolu, Kayseri: M Grup Matbaacilik.

Kee, T. (2019). Sustainable adaptive reuse - economic impact of cultural heritage. Journal of Cultural Heritage Management and Sustainable Development, 165-183.

Kervankiran, İ. (2014). Dünyada değişen müze alg1s1 ekseninde Türkiye'deki müze turizmine bakış. Turkish Studies-International Periodical for the Languages, Literature and History of Turkish or Turkic, 9(11), 345-369.

Kişisel arşiv, (2020). Milli Mücadele Müzesi görselleri.

Kocabıyık, Y. (2014). Yeniden işlevlendirme kavramı ve bu kapsamda İTÜ Taşkışla binasının incelenmesi (Yayımlanmamış yüksek lisans tezi). Marmara Üniversitesi, İstanbul.

Kuban, D. (2000). Tarihi Çevre Korumanın Mimarlık Boyutu Kuram ve Uygulama. İstanbul: Yap1 Endüstrisi Yayını.

Kurak Açıcı, F. ve Konakoğlu, Z.N. (2019). Tarihi yapıların yeniden işlevlendirilmesi: Trabzon Mimarlar Odası örneği. Ç. Ü. Sosyal Bilimler Enstitüsü Dergisi. 28(2), 214-224.

Kültür ve Turizm Müdürlüğü. (2009). Kayseri taşınmaz kültür varlıkları envanteri, 1.Cilt, T.C Kayseri Valiliği, Kayseri: Kültür ve Turizm Müdürlüğü Yayınları.

Langston, C., Wong, F.K., Hui, E., and Shen, L. (2008). Strategic assessment of building adaptive reuse opportunities in Hong Kong. Building and Environment, 43, 1709-1718.

MEB, Kayseri Lisesi Tarihçesi (2018). https://kayserilisesi.meb.k12.tr/icerikler/okulumuzuntarihcesi_4354620.html [Erişim Tarihi: 28.04.2021]

Misırlisoy, D. ve Günçe, K. (2016). Assessment of the adaptive reuse of castles as museums: case of Cyprus, International Journal of Sustainable Development and Planning, 11(2), 147-159.

Özdemir, İ.M., Kars, F.B. ve Şahin, Ş. (2005). İşlevsel ve fiziksel eskimeye alternatif bir tasarım: KTÜ hangar binasının kafeteryaya dönüşmesi, Tasarım, Tasarım Yayın Grubu, İstanbul, 153, 100-3.

Özmerdivenli, Y. (1997). Kayseri Lisesi 100. y1l şeref belgeseli (1. Cilt), Kayseri Lisesi’nin eğitim-öğretim tarihindeki yeri ve önemi, (ss. 104-108). Ankara: Arman Ofset Matbaacilik. http://www.yusufozmerdivenli.com.tr/pdf/serefbelges eli/kayseri_lisesi_1cilt_parca1_giris_ve 18931996_egitim_kadrosu.pdf

Pehlivan, G.F. (2018). Anıtsal Türk mimarlık örneklerinden Deveci Han'1n yeniden işlevlendirilmesi. SUTAD, (43), 537-559.

Pereira Roders, A. (2007). RE-ARCHITECTURE: Lifespan rehabilitation of built heritage. Eindhoven: Eindhoven University of Technology. 
Plevoets, B. and Van Cleempoel, K. (2011). Adaptive reuse as a strategy towards conservation of cultural heritage: a literature review. Proceedings Structural Studies, Repairs and Maintenance of Heritage Architecture XI, Chianciano Terme, Italy.

Sağıroğlu Arslan, A. (2014). Kayseri'nin ilk modern eğitim yapısı: Kayseri Lisesi. Sosyal Bilimler Enstitüsü Dergisi, 36 (1), 1-33.

Selçuk, M. (2006). Binaların Yeniden Işslevlendirilmesinde Mekânsal Kurgunun Değerlendirilmesi (Yayımlanmamış yüksek lisans tezi). Selçuk Üniversitesi, Konya.

Warren, J., J.Worthington, ve S.Taylor. (1998). Context: New Buildings in Historic Settings. Boston: Architectural Press.

Venedik Tüzüğü. (1964). Uluslararası Tarihi Anıtları Koruma Kuralları.

Yalaz, E.T. ve Yaldız, E. (2020). Yeniden Kullanım Sonrası Yapısal Müdahalelerin Değerlendirilmesi, Tantavi Ambarı Örneği. Artium, 8 (2), 105-117.

Yalçınkaya, Ş. ve Bal, H. B. (2019). Cumhuriyet Dönemi Mimarlık Mirasının Sürdürülebilirliği: Karabük Yenişehir Sinemas1. Journal of Social and Humanities Sciences Research. 6(42), 2685-2692.

Yalçınkaya, Ş., Kurak Açıcı, F., ve Faiz Büyükçam, S. (2019). Tarihi çevrede yeni yapı tasarımı ve Daniel Libeskind, Uluslararası Karadenize Kıyısı Olan Ülkeler Sempozyumu, IKSAD, Samsun.

Yaldız, E. (2003). Konya'daki medrese yapılarının yeniden kullanım koşullarına göre değerlendirilmesi (Yayınlanmamış Yüksek Lisans Tezi), Selçuk Üniversitesi, Konya.

Yaldız, E. ve Gül Asatekin, N. (2016). Anıtsal yapıların kullanım sürecinde değerlendirilmesine yönelik bir model önerisi, METU.JFA, 33(2): 161-182.

Yeğen, A. (1993). Kayseri'de Tarihi Eserler, Kayseri: Kayseri İl Kültür Müdürlüğü.

Yüce, A. İ. (1981). Medrese yapıları ve koruma ilkeleri doğrultusunda çağdaş yaşam içindeki işlevleri, Doktora Tezi, MSÜ, İstanbul. 